\title{
IMPACT OF DEMONETIZATION ON FINANCIAL INCLUSION IN INDIA: A STUDY WITH EVIDENCE OF EMERGING DIGITAL FINANCIAL SERVICES
}

\author{
Dr. Muhammed Shafi M K \\ Assistant Professor, VIT Business School, Vellore Institute of Technology, \\ Chennai, Tamil Nadu-India. \\ Dr. Sudheer Muhammed K M \\ Assistant Professor, VIT Business School, Vellore Institute of Technology, \\ Chennai, Tamil Nadu-India.
}

\begin{abstract}
This paper seeks to analyze the immediate impact of demonization drive on digital financial inclusion in India which was declared on 8th November 2016. Thereafter, digital financial inclusion got wide momentum in terms of accessibility and usability than ever before. Thus, the study is ascertained to explore the emerging trends in the financial sector for financial inclusion in India followed by discussions on prospects and challenges of financial technology (Fintech) that occurred due to demonetization ordinance. So far none of the studies was performed in analytical way to explore the impact of new demonetization ordinance on digital financial inclusion. Hence, this approach is the first dimension in this respect with the discussions on emerging techbased financial services. The study encompasses the analysis of financial inclusion parameters like opening Bank account, No Frills Account (NFA) and Rupay Debit Card with the comparison of pre and Post periods of demonetization. Paired Sample t-test was applied to test the hypotheses and results show that those three parameters do not have a significant impact on financial inclusion due to demonetization except in the distribution of Rupay Debit card provided by Public sector banks.
\end{abstract}

JEL Classification: E60, G21, G28, P00.

Key words: Digital Financial Inclusion, Demonetization, No Frills Accounts (NFA), Rupay Debit Cards, Payment Banks 
Impact of Demonetization on Financial Inclusion in India: A Study with Evidence of Emerging

Digital Financial Services

Cite this Article: Muhammed Shafi M K and Sudheer Muhammed K M, Impact of Demonetization on Financial Inclusion in India: A Study with Evidence of Emerging Digital Financial Services, International Journal of Management, 11(12), 2020, pp. 2807-2819.

http://iaeme.com/Home/issue/IJM?Volume=11\&Issue=12

\section{INTRODUCTION}

The driven force of 'Digital India' mission was subjected to strong impact on digital financial inclusion especially after the demonetarization declaration on $8^{\text {th }}$ November, 2016. The Financial Inclusion is the delivery of banking services at an affordable cost to the vast section of the unbanked group. After the massive mission of Pradhan Mantri Jah-Dhan Yojana (PMJDY) in India, financial inclusion is vigorously promoted to ensure delivery of banking services at an affordable cost to the unbanked group. Subsequently, various measures have been taken by banks, GOI (Government of India) and RBI for financial inclusion plan like Product Based Approach, Bank Led approach, Business Correspondents (BCs), Simplified KYC Norms etc.

While demonetization experiment move is remained debatable in many aspects, which was considered as the noble idea to curb the counterfeit currency, corruption, terror financing and to discourage tax evasion on undeclared income. As the consequences of demonetization, digital financial movements like e-money accounts provided by banks, mobile banking, Peerto-Peer (P2P) lending banks got wide attention and e-wallet companies got rapid growth in terms of money transactions on their web and app-based platforms. But these are mostly mobilized only in urban and metropolitan areas of the country. Companies like Paytm, PayU India, MobiKwik and Freecharge already grabbed tremendous results within few hours of demonetization drive. Most e-wallet firms also set their direction to enable the online payment facilities by tying up with merchants. The project of 'Digital India' is much ambitious to empower and transform our country into a digitalized knowledge economy. This initiative is revolutionizing the financial access, thus it increases the willingness of people to use internet and smartphone for the financial transaction.

The present phenomenon of demonetization has brought an adverse impact on the rural economy and hindered growth of the rural areas of the country, where cash-based transactions are widely used with limited physical accessibility to the direct banking services. The relevance of Intermediary channel like Business correspondent (BC) is well subjected in this context which can connect the unbaked or rural people with the banking sector directly. Further, the present digital financial services like ATMs and Point of Sale (POS) machines at shops are not well versed and crippled with infrastructural issues. So that ordinary residents are constrained to access such services conveniently. Therefore, this study is trying to illustrate such kind of hurdles and future prospects based on current outreach of digital financial services and to discuss the impact of demonetization on financial inclusion through the digital accessibility and affordability.

\section{REVIEW OF LITERATURE}

A couple of studies have been done pertaining to financial inclusion and digital banking based on different variables such electronic banking, Financial inclusion initiatives, Regulatory framework for digital banking and Financial Inclusion etc. The relevant literatures on this topic have been furnished below.

Schueth. S, Alex Moler. (2017) did a survey on financial inclusion in the light of demonization with sample size of 1600 , they were selected randomly from the sates such as 
Madya Pradesh, Gujarat and Rajasthan. The study carried out demographic analysis and obtained the conclusion that prior to demonetization, around half of the panelists were nonusers of financial institutions, whereas, nonusers were decreased sharply to $19 \%$ of the panelists in the later stage of demonetization. Based on 90 days performance, the active users of financial accounts were increased to $51 \%$ of panelists after the demonetization from $34 \%$ rate of predemonetization. The study also draws the findings that all demographic groups showed gains in financial inclusion after demonetization. NBFC account holders also increased which was driven by the role of post office banks, whereas same impact is not meaningfully resulted in case of payment banks.

Susy Cheston et al (2016) indicated that digital financial revolution is underway in many banking industries. Today banks can take up innovative technologies to transform how banking services are delivered to their existing customers and how are new avenues being implemented in a prominent manner. The paper also elucidates the leadership of banks in financial inclusion and giving many examples like and people-to-business payments (P2B) such as e-commerce, merchant and ticket payments, bill payments and person-to-person (P2P) based banks, which are innovated to reaching out into underserved areas.

According to Ajit Deshmukh (2016) Indian financial services landscape is undergoing a technology-driven shift. Government has leveraged its approach to achieve financial inclusion with the help of digitalized technology in banking services. The steps taken by RBI on financial inclusion was much needed and intensively supported to digital infrastructure to reach the unbanked areas. Banks need to target such outskirt and financially excluded segments through technology-enabled services which can provide the necessary transactions.

John D. Villasenor et al (2016) did a study based on digital financial inclusion across the globe, in which the author articulated that Kenya retained highest ranked country with 5\% point margin. The other top-scoring countries are Colombia (earning 79 percent of the total possible score), and South Africa, Brazil, and Uganda (tied at 78 percent each). India scored $71 \%$ and its other parameters and score are commitment score is $100 \%$, Mobile Capacity is $72 \%$, Regulatory Environment is $94 \%$ and adoption is $44 \%$.

CRISIL Inclusix (2015) developed a comprehensive index to measure financial inclusion in India which mainly relies on three parameters such as branch penetration (BP), deposit penetration (DP) and credit penetration (CP). This report shows the all India CRISIL Inclusix score, which is 50.11 out of 100 at the end of fiscal 2013. There are nine districts in India with CRISIL Inclusix score of 100 and total 82.0 crore saving bank accounts exist in India (As of 2013).

Sa-Dhan (2015) report envisaged the financial inclusion through Business Correspondent model by using Information and Communication Technology (ICT). BC services are provided through technology-based banking systems which enable the people in unbanked areas to access banking services with easy affordability. Further, the report highlighted the demand-side and supply-side issues of financial inclusion. In this respect, the study indicated the major rural people are low income and low asset holders so that they are not demanding such financial services. On the other hand, inappropriate accessibility and non-reaching out of banking services to a wider section of society including the poor and vulnerable stand as supply side issue. Such hurdles arise due to high cost and can be defeated through ICT solutions.

Neeru Chhabra (2014) did an empirical research based on 1000 sample size and secondary data in between 2001 and 2010. The work identified four parameters to analyze the impact of Financial Inclusions, namely; Bank Branches, Credit Account, Savings Account and CreditDeposit Ratio. The chapters show comparative study among these parameters during the period 2000-2010. 
Rajaswaminathan (2013) reviewed the role of Business Correspondents as it is mode to employ the banking services in unbanked areas. Banking branches are not rolled out enough to attain full financial inclusion in India because the country has more wide area and regional imbalances in which varies like rural, semi-urban, urban and metropolitan. As the result, the GOI introduced new paradigm such as BCs to connect the people in rural and urban areas in the banking fold with a neighboring approach.

Ujjawal, A (2012) conducted a study based on five business correspondent companies named FINO Fintech Foundation, Little World, Eko Aspire Foundation, Samvriddhi Trust and Janalakshmi Social Services. Additionally, a caselet for Cashpor Micro Credit (CMC) also has been included. The sample survey consisted of 67 agents. Around half of the surveyed agents said that they did not face any competition in BC sector. One-third of the agents said that banks are their main competitors and that people would open accounts in banks. The survey indicates that there is a lack of knowledge among the clients about the features of the No frills Accounts (NFAs) and limitations of NFAs.

\section{RESEARCH GAP AND PROBLEM}

Even some studies already did on digital financial inclusion, financial literacy, Business Correspondent etc such studies discussed only on typical financial services and initiatives taken by GOI and other institutions. But this study was conducted in the context of recent movements of demonetization in India and subsequent initiatives for the digital financial economy. Additionally, this study dwells prospects and challenges of financial technology (Fintech) which can be implemented with more accessibility and affordability to tackle the liquidity crunch occurred after demonetization.

In brief, so far there is no any study has done on digital financial inclusion based on the current evidence of demonetization and its impact. Moreover, this study is an attempt to address the arising questions like what is impact of demonetization on financial inclusion, how does demonetization result on outreach of digital financial services, what are the measures to solve supply and demand side issues of finance affected by demonetization and what are the emerging trends in digital financial services.

\section{OBJECTIVES OF THE STUDY}

- To analyze the impact of demonetization on digital financial inclusion in India.

- To assess the outreach of financial services during pre and post periods of demonetization

- To discuss the prospects and challenges of moving towards digital financial services

\section{HYPOTHESES}

H01-There is no significant difference between in number of Rupay Debit Cards during pre and post periods of demonetization

H02-There is no significant difference between in number of accounts opened during pre and post periods of demonetization

H03-There is no significant difference between in number of Zero Balance Accounts (NFA) during pre and post periods of demonetization

\section{RESEARCH METHODOLOGY}

This is a quantitative assessment study based on exploratory research method. The objectivity of the study has been ascertained with the help of secondary data collected from websites like 
PMJDY, NPCI, Digital India and other sources related to demonetization and financial inclusion. The data have been collected on short term basis (September 2016 to January 2017) which were computed in a fortnight interval period to draw the conclusion more fruitfully.

\subsection{Data Analysis Methods}

The data have been analyzed with respect to pre and post outreach of financial services such as Rupay Debit Cards, No Frills Accounts (NFA) and Number Bank Accounts Opened. It also focuses on IMPS, NEFT, RGTS and POS terminal transactions to know the impact of demonetization on financial inclusion. To test the hypotheses, Paired sample t-test (i.e. dependent sample $t$-test) was performed with the help of SPSS which measures the mean difference like before and after observations on same subjects.

\section{FINANCIAL INCLUSION IN INDIA}

During the last decades of Indian financial system, tremendous financial changes were taken place in different financial sectors like two reforms $(1969,1980)$ in banking sector to nationalize twenty banks, establishment of Regional Rural Banks (RRBs) in the year of 1975 and initiation of Self-Help Group Bank Linkage Program (SHG-BLP) in 1992 by NABARD. For achieving financial inclusion in India, GOI and RBI have taken various measures such as Product Based Approach (like Kisan Credit Cards (KCC), General Purpose Credit Cards), Bank-Led approach (like Business Correspondents, Self Help Group-Bank Led Program (SLBP), product led approach, Knowledge Based Approaches (opening Financial Literacy Centers and Financial Literacy Guide,), Government initiatives (such as PMJDY and MGNREGA), Technology-based approach (like Kiosk Banks, Aadaar Enabled Banking services etc) and Regulatory approaches (like simplifying KYC). Furthermore, many modifications and regulations have been brought by Governing authorities like RBI, Ministry of Finance, central and state governments to ensure the financial Inclusion through the Banks like Priority Sector Lending, PMJDY, Business Correspondent etc.

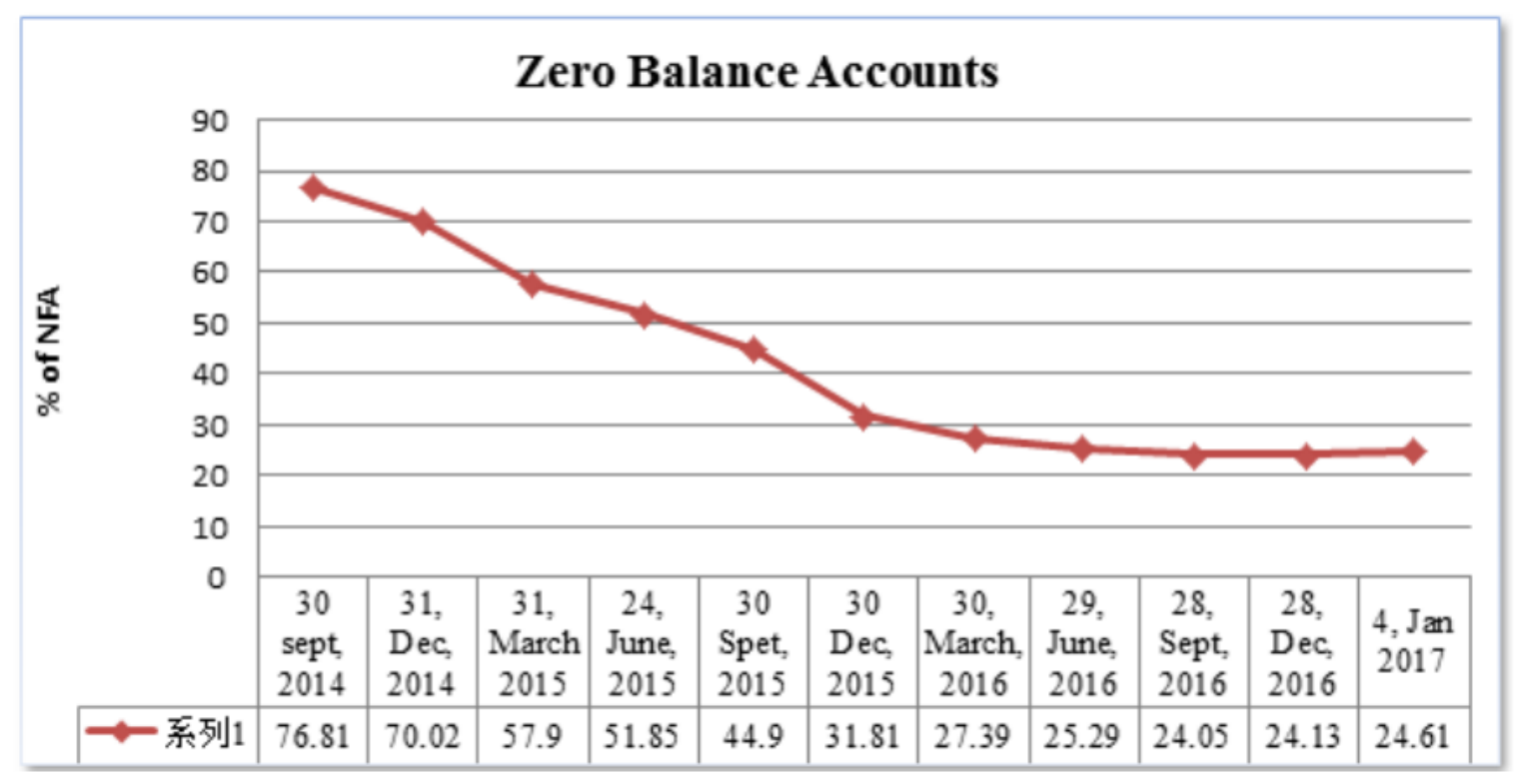

Figure 1 Number of Zero Balance Account

Source: PMJDY Website

Even many these kinds of financial inclusion initiatives were brought by different authorities and financial institutions, still comprehensive financial inclusion is much away from the destination. As on 22nd January 2020, total beneficiaries under the PMJDY is 37.95 core 
and 29.86 crore Rupay Debit Cards were issued to beneficiaries. Whereas, on 04th January, 2017, the total bank account opened under PMJDY scheme account for 26.61 crore, of which $24.61 \%$ are zero balance account (PMJDY Website). The details of zero balance account under Jan Dhan during post and pre periods of demonetization are given below.

The above chart shows that even there is a substantial decrease in zero balance accounts from 76.81 on $30^{\text {th }}$ Sept, 2016, still $24.61 \%$ bank account are dormant even after lots of savings reached to Jan Dhan Accounts in the aftermath of recent demonetization in India. It indicates that the comprehensive inclusion may take more time rather than just opening bank to consider them all truly included.

\section{IMPACT OF DEMONETIZATION ON FINANCIAL INCLUSION}

To analyze the impact of demonetization on financial inclusion three parameters have been chosen based on the availability of data which are 1-Number of Rupay Debit Card, 2-Number of Account Opened and 3-Number of No Frills Accounts (NFA). Their detailed analyses have been given below.

\subsection{Number of Rupay Debit Cards}

RuPay is an India's domestically developed card launched by the National Payments Corporation of India (NPCI) in 2012. It addresses all needs of Indian customers and merchants due to its flexibility, lower cost and affordability. RuPay card transactions will not be passed outside India so as it ensure security. It got wider outreach in rural areas and accepted over 10,000 e-commerce websites and more than 8 lakh Point of Sale (POS) terminals. More than 600 banks are issuing RuPay Debit Cards and presently over 300 million such cards are in circulation (Bankbazar.com, 22-Nov-2016). This is considered as import factor for financial inclusion, especially under PMDJY scheme. The details of number of Rupay Debit Card during Pre and Post period of Demonetization period i.e. 28.09.16 and 04.01.17 are as furnished below.

Table 1 Number of Rupay Debit Cards across Public, Private and RR Banks

\begin{tabular}{|l|c|c|c|c|c|c|}
\hline \multirow{2}{*}{ Banks } & \multicolumn{3}{|c|}{$\begin{array}{c}\text { No of Rupay Debit Cards-Pre } \\
\text { Demonetization Period }\end{array}$} & \multicolumn{3}{c|}{$\begin{array}{c}\text { No of Rupay Debit Cards-Post } \\
\text { Demonetization Period }\end{array}$} \\
\cline { 2 - 7 } & $\begin{array}{c}\mathbf{2 8 - 0 9 . 1 6} \text { to } \\
\mathbf{1 2 - 1 0 - 1 6}\end{array}$ & $\begin{array}{c}\mathbf{1 2 . 1 0 . 1 6} \text { to } \\
\mathbf{2 6 . 1 0 . 1 6}\end{array}$ & $\begin{array}{c}\mathbf{2 6 . 1 0 . 1 6} \\
\text { to 9.11.16 }\end{array}$ & $\begin{array}{c}\mathbf{2 3 . 1 1 . 1 6} \text { to } \\
\mathbf{7 . 1 2 . 1 6}\end{array}$ & $\begin{array}{c}\mathbf{7 . 1 1 . 1 6} \text { to } \\
\mathbf{2 1 . 1 2 . 1 6}\end{array}$ & $\begin{array}{c}\mathbf{2 1 . 1 2 . 1 6} \text { to } \\
\mathbf{0 4 . 1 . 1 7}\end{array}$ \\
\hline $\begin{array}{l}\text { Public Sector } \\
\text { Bank }\end{array}$ & 1238363 & 726930 & 681732 & 3044619 & 3659005 & 3097186 \\
\hline $\begin{array}{l}\text { Regional Rural } \\
\text { Bank }\end{array}$ & 26451 & 924776 & 32123 & 3334463 & -6014015 & 6771592 \\
\hline Private Banks & -30295 & 66573 & -242391 & 629 & 74253 & 101235 \\
\hline Total & 1234519 & 1718279 & 471464 & 6379711 & -2280757 & 9970013 \\
\hline
\end{tabular}

Source: PMJDY Website, 2017 http://pmjdy.gov.in/Archive

From the table (Table-1), it can be evident that even there is a slowdown in number of Rupay Cards of RRBs and in total distribution during 7.11.16 to 21.12.16 fortnight, the subsequent fortnight covered all such drops with the augmentation of 99,70,013 cards in total and 67,71,592 Rupay cards in RRB as post result of demonetization.

To analyze the impact of demonetization on number of Rupay Debit Card following Hypothesis and analysis have been framed out. 


\section{Test of Hypothesis-1}

H01-There is no significant difference between in number of Rupay Debit Cards during pre and post periods of demonetization

This inferential test has been done based on three banking sector such as Public, Private and Regional and Rural Banks (RRB). Further, the test also was executed on total number of Rupay Cards distributed over all these three sectors.

Table 2 Output table of Paired Samples t-Test on Rupay Debit Card Distribution

\begin{tabular}{|c|c|c|c|c|c|c|c|}
\hline \multirow{2}{*}{} & \multicolumn{2}{|c|}{ Mean } & \multicolumn{2}{|c|}{$\begin{array}{c}\text { Paired Differences } \\
\text { Differences }\end{array}$} & \multirow{2}{*}{$\begin{array}{c}\text { Sig. (2- } \\
\text { tailed) }\end{array}$} \\
\cline { 3 - 5 } & & Lower & Upper & & Df & & \\
\hline Pair 1 & $\begin{array}{c}\text { Pre and Post-Rupay- } \\
\text { Public Sector Banks }\end{array}$ & -2384595.00 & -3784514.74 & -984675.25 & -7.329 & 2 & $\mathbf{. 0 1 8}$ \\
\hline Pair 2 & Pre and Post-Rupay-RRB & -1036230.00 & -18714573.68 & 16642113.68 & -.252 & 2 & $\mathbf{. 8 2 4}$ \\
\hline Pair 3 & $\begin{array}{c}\text { Pre and Post-Rupay- } \\
\text { Private Sector Banks }\end{array}$ & -127410.00 & -593456.28 & 338636.28 & -1.176 & 2 & $\mathbf{. 3 6 1}$ \\
\hline Pair 4 & $\begin{array}{c}\text { Total comparison of } \\
\text { Rupay Cards }\end{array}$ & -3548235.00 & -20661564.80 & 13565094.80 & -.892 & 2 & $\mathbf{. 4 6 6}$ \\
\hline
\end{tabular}

Source: SPSS output Table

The SPSS output table (Table-2) on four paired t-test shows that all hypotheses are statistically insignificant i.e. its 2 tailed value is more than .05 (Alpha) except number of Rupay debit Card of Public sector Banks $(\mathrm{P}$ value $=0.018)$ i.e. it rejects the null hypothesis. Hence, it can be commented on above hypotheses testing that there is no significant impact of demonetization on number of Rupay debits Cards across RRB and Private Banks and total distribution except on Public sector Banks.

\subsection{Number of Bank Accounts Opened}

The details of the number of account opened during pre and post periods of demonetization have been given below.

Table 3 Number of Bank Accounts Opened across Public, Private and RR Banks

\begin{tabular}{|l|c|c|c|c|c|c|}
\hline \multirow{2}{*}{ Banks } & \multicolumn{3}{|c|}{ Pre Demonetization Period } & \multicolumn{3}{c|}{ Post Demonetization Period } \\
\cline { 2 - 7 } & $\begin{array}{l}\mathbf{2 8 - 0 9 . 1 6} \text { to } \\
\mathbf{1 2 - 1 0 - 1 6}\end{array}$ & $\begin{array}{l}\mathbf{1 2 . 1 0 . 1 6} \text { to } \\
\mathbf{2 6 . 1 0 . 1 6}\end{array}$ & $\begin{array}{l}\mathbf{2 6 . 1 0 . 1 6} \text { to } \\
\mathbf{9 . 1 1 . 1 6}\end{array}$ & $\begin{array}{l}\mathbf{2 3 . 1 . 1 6} \text { to } \\
\mathbf{7 . 1 2 . 1 6}\end{array}$ & $\begin{array}{l}\mathbf{7 . 1 1 . 1 6} \text { to } \\
\mathbf{2 1 . 1 2 . 1 6}\end{array}$ & $\begin{array}{l}\mathbf{2 1 . 1 2 . 1 6} \text { to } \\
\mathbf{0 4 . 1 . 1 7}\end{array}$ \\
\hline $\begin{array}{l}\text { Public Sector } \\
\text { Bank }\end{array}$ & 3065735 & 2030478 & 1918561 & 697237 & 2195954 & 4357206 \\
\hline $\begin{array}{l}\text { Regional Rural } \\
\text { Bank }\end{array}$ & 131913 & 544533 & 281163 & 761814 & -113613 & 317308 \\
\hline Private Banks & -39034 & 72745 & -247186 & 5180 & 11042 & 75880 \\
\hline Total & $\mathbf{3 1 5 8 6 1 4}$ & $\mathbf{2 6 4 7 7 5 6}$ & $\mathbf{1 9 5 2 5 3 8}$ & $\mathbf{1 4 6 4 2 3 1}$ & $\mathbf{2 0 9 3 3 8 3}$ & $\mathbf{4 7 5 0 3 9 4}$ \\
\hline
\end{tabular}

Source: PMJDY Website, 2017 http://pmjdy.gov.in/Archive

The table indicates there is a gradual increase of opening bank accounts across all banks and there is 47,50,394 bank account opened during 21.12. 16 to 04.1.2017 and this is highest in terms of fortnight data on number of accounts. 
Impact of Demonetization on Financial Inclusion in India: A Study with Evidence of Emerging Digital Financial Services

\section{Test of Hypothesis-2}

H02-There is no significant difference between in number of accounts opened during pre and post periods of demonetization.

The test is based on data of three banking sector such as Public, Private and Regional and Rural Banks (RRB). Further, the test was done based on total number of accounts also.

Table 4 Output table of Paired Samples t-Test on Number of Bank Accounts Opened

\begin{tabular}{|c|c|c|c|c|c|c|c|}
\hline \multicolumn{8}{|c|}{ Paired Samples t-Test } \\
\hline & & \multicolumn{3}{|c|}{ Paired Differences } & \multirow{3}{*}{$\mathrm{t}$} & \multirow{3}{*}{ Df } & \multirow{3}{*}{$\begin{array}{l}\text { Sig. (2- } \\
\text { tailed) }\end{array}$} \\
\hline & & \multirow[t]{2}{*}{ Mean } & \multicolumn{2}{|c|}{$\begin{array}{c}95 \% \text { Confidence Interval of } \\
\text { the Differences }\end{array}$} & & & \\
\hline & & & Lower & Upper & & & \\
\hline Pair 1 & $\begin{array}{l}\text { Pre \& post-No of } \\
\text { Account-Public } \\
\text { Sector Banks }\end{array}$ & -78541.00 & -6052272.02 & 5895190.02 & -.057 & 2 & .960 \\
\hline Pair 2 & $\begin{array}{l}\text { Pre \& post-No of } \\
\text { Account-RRB }\end{array}$ & -2633.33 & -1604099.98 & 1598833.32 & -.007 & 2 & .995 \\
\hline Pair 3 & $\begin{array}{c}\text { Pre \& post-No of } \\
\text { Account-Private } \\
\text { Sector Banks }\end{array}$ & -101859.00 & -595596.63 & 391878.63 & -.888 & 2 & .468 \\
\hline Pair 4 & $\begin{array}{c}\text { Pre \& Post-Total } \\
\text { Number of Account }\end{array}$ & 82269599.00 & -276558537.6 & 441097735.60 & .986 & 2 & .428 \\
\hline
\end{tabular}

Source: SPSS output Table

From the table (Table-4), it can be understood that all P Values are more than Alpha Value (0.05), so that all inferences are rejecting Alternative hypotheses (H1). Therefore, it can be stated on above test that there is no significant impact of demonetization on number of bank accounts opened.

\subsection{No Frills Accounts (NFA)}

The details of No Frills Account (Zero Balance Account) opened under the different banking sectors during pre and post period of demonetization are given below

Table 5 Number of No Frills Accounts (NFA) across Public, Private and RR Banks

\begin{tabular}{|l|c|c|c|c|c|c|}
\hline \multirow{2}{*}{ Banks } & \multicolumn{3}{|c|}{ Pre Demonetization Period } & \multicolumn{3}{c|}{ Post Demonetization Period } \\
\cline { 2 - 7 } & $\begin{array}{l}\mathbf{2 8 - 0 9 . 1 6} \text { to } \\
\mathbf{1 2 - 1 0 - 1 6}\end{array}$ & $\begin{array}{l}\mathbf{1 2 . 1 0 . 1 6} \text { to } \\
\mathbf{2 6 . 1 0 . 1 6}\end{array}$ & $\begin{array}{l}\mathbf{2 6 . 1 0 . 1 6} \text { to } \\
\mathbf{9 . 1 1 . 1 6}\end{array}$ & $\begin{array}{l}\mathbf{2 3 . 1 . 1 6} \text { to } \\
\mathbf{7 . 1 2 . 1 6}\end{array}$ & $\begin{array}{l}\mathbf{7 . 1 1 . 1 6} \text { to } \\
\mathbf{2 1 . 1 2 . 1 6}\end{array}$ & $\begin{array}{l}\mathbf{2 1 . 1 2 . 1 6} \text { to } \\
\mathbf{0 4 . 1 . 1 7}\end{array}$ \\
\hline $\begin{array}{l}\text { Public Sector } \\
\text { Bank }\end{array}$ & -347857 & 91527 & 124816 & 410450 & 2702645 & 2994058 \\
\hline $\begin{array}{l}\text { Regional } \\
\text { Rural Bank }\end{array}$ & -162671 & 262383 & -4392 & -13469 & 122952 & 162615 \\
\hline $\begin{array}{l}\text { Private } \\
\text { Banks }\end{array}$ & -29586 & 25054 & -89516 & -13742 & -35000 & -22429 \\
\hline Total & $\mathbf{- 5 4 0 1 1 4}$ & $\mathbf{3 7 8 9 6 4}$ & $\mathbf{3 0 9 0 8}$ & $\mathbf{3 8 3 2 3 9}$ & $\mathbf{2 7 9 0 5 9 7}$ & $\mathbf{3 1 3 4 2 4 4}$ \\
\hline
\end{tabular}

Source: PMJDY Website, 2017 http://pmjdy.gov.in/Archive

From the table (Table-5) it can be inferred that there is an increasing trend of NFAs in Post demonetization period, further in between 21.12.16 and 04.1.17, it increased up to 31,34,244, which is highest ever. Basically, NFA should be reduced, unless it will be just like idle or dormant account without any financial transactions. The formal digital financial inclusion will 
be possible if the numbers of these accounts are reduced and most of the zero balance accounts are existing in Public sector Banks.

\section{Test of Hypothesis-3}

H03-There is no significant difference between in number of Zero Balance Accounts (NFA) during pre and post periods of demonetization

As mentioned above, this test also was conducted based on three banking sector data and its total figure.

Table 6 Output table of Paired Samples t-Test on No Frills Accounts (NFA)

\begin{tabular}{|c|c|c|c|c|c|c|c|}
\hline \multicolumn{8}{|c|}{ Paired Samples Test } \\
\hline & & \multicolumn{3}{|c|}{ Paired Differences } & \multirow{3}{*}{$\mathrm{t}$} & \multirow{3}{*}{ Df } & \multirow{3}{*}{$\begin{array}{l}\text { Sig. (2- } \\
\text { tailed) }\end{array}$} \\
\hline & & \multirow{2}{*}{ Mean } & \multicolumn{2}{|c|}{\begin{tabular}{|c|}
$\begin{array}{c}95 \% \text { Confidence Interval of } \\
\text { the Difference }\end{array}$ \\
\end{tabular}} & & & \\
\hline & & & Lower & Upper & & & \\
\hline Pair 1 & $\begin{array}{l}\text { Pre \& Post-NFA - } \\
\text { Public Sector Banks }\end{array}$ & -2079555.66 & -4940016.81 & 780905.47 & -3.12 & 2 & .089 \\
\hline Pair 2 & $\begin{array}{c}\text { Pre \& Post-NFA - } \\
\text { RRBs }\end{array}$ & -58926.00 & -486229.30 & 368377.30 & -.59 & 2 & .613 \\
\hline Pair 3 & $\begin{array}{l}\text { Pre \& Post-NFA - } \\
\text { Private Sector Banks }\end{array}$ & -7625.66 & -166530.19 & 151278.86 & -.206 & 2 & .856 \\
\hline Pair 4 & $\begin{array}{c}\text { Pre \& Post-NFA - } \\
\text { Total }\end{array}$ & -2146107.33 & -4913395.91 & 621181.24 & -3.33 & 2 & .079 \\
\hline
\end{tabular}

Source: PMJDY Website, 2017 http://pmjdy.gov.in/Archive

The paired sample t-test result table (Table-6) on NFA shows that all Sig. (2-tailed) values are above 0.05 . A degree of Freedom (df) is 2 and total t-value is -3.33 . Hence, in this case also all hypotheses are accepting null hypothesis and can be commented that there is no significant impact of demonetization on Zero balance account or No Frills Accounts across all private, public and RRBs.

\subsection{Other Digital Financial Services}

Consequent to the demonization drive, the Immediate Payment Service (IMPS) rolled out immensely as an effective mobile payment system in India, which was launched by National Payment Corporation of India (NPCI), a non-profit company by enabling $24 \times 7$ instant funds transfer to any bank account in India through the low-cost device or a high-end Smartphone. For this MMID (Mobile Money Identifier) is issued by banks to the customers when IMPS is registered. NCPI is considered as a paramount institute for all retail payments in India, which state that the number of daily transactions on the UPI platform has doubled with 4.2 million registered users since demonetization, in which Paytm claims 170 million as a wallet player (Rajiv Singh, 2017). The below table shows the data on NPCI connected digital transaction under different categories.

Table 7 NPCI Payment based on Digital Transactions (Volume in Millions)

\begin{tabular}{|l|l|l|l|l|l|l|c|}
\hline $\begin{array}{c}\text { Methods of } \\
\text { Digital } \\
\text { Transactions }\end{array}$ & Apr'16 & June'16 & Sept'16 & Dec'16 & \multicolumn{1}{|c|}{ Jan'17 } & $\begin{array}{c}\text { March, } \\
\mathbf{2 0 1 8}\end{array}$ & $\begin{array}{c}\text { March } \\
\mathbf{2 0 1 9}\end{array}$ \\
\hline IMPS Payments & 26.78 & 29.68 & 35.93 & 52.86 & 62.42 & 110.15 & 190.18 \\
\hline Mobile Banking & 48.38 & 62.52 & 72.63 & 89.61 & 106.13 & 237.67 & 867.41 \\
\hline
\end{tabular}


Impact of Demonetization on Financial Inclusion in India: A Study with Evidence of Emerging Digital Financial Services

\begin{tabular}{|l|l|l|l|l|l|l|c|}
\hline m-Wallet & 48.76 & 58.63 & 75.30 & 213.11 & 261.67 & 268.79 & 384.89 \\
\hline $\begin{array}{l}\text { Number of NEFT } \\
\text { Transactions }\end{array}$ & 111.84 & 118.29 & 120.15 & 166.31 & 164.19 & 212.01 & 242.39 \\
\hline $\begin{array}{l}\text { Number of RGTS } \\
\text { Transactions }\end{array}$ & 8.3 & 8.8 & 8.4 & 8.8 & 9.33 & $11.2 *$ & - \\
\hline $\begin{array}{l}\text { Number of POS (in } \\
\text { actual) }\end{array}$ & 1400792 & 1432727 & 1480309 & 1705423 & 2015847 & 3193356 & 3722229 \\
\hline
\end{tabular}

*As on January 2018

Source: NPCI \& RBI Bulletin 2016-19

The above table (Table No-7) deals with statistical data on digital transactions over IMPS, NEFT, RGTS, m-Wallet and Number of Point of Sale (POS). The overall data reveal that there is an increasing trend in the digital transaction in all subsequent months but phenomenal changes were taken place in post demonetization period. The total number of POS was scaled up 37,22,229 in March 2019 whereas it was only 20,15,847 in January 2017. Similarly, IMPS, Mobile Banking, M-Wallet, NEFT and RGTS transactions also were increased exponentially during post period of demonetization period especially m-wallet which was only 75.30 million in September 2016 and scaled up 213.11 million in December 2016 which is considered as the immediate effect of demonetization in India.

There are 498 member banks have been associated with for IMPS enabled services as per the statistics of NPCI. Further, 141 live banks provides Unified payment interface (UPI) facilities by which quick and easy payment is done without much hassle. The Micro ATMs have been transformed to UIDAI authentications, as on May 2019 the total volume of intra bank UIDAI authentication covered 310 million (Source: NPCI website).

\section{LOOKING FORWARD: PROSPECTS AND CHALLENGES}

Presently, Central Government and Financial Institutions are much focusing on cashless economy. Although, still its outreach into rural and undeserved areas are not well deployed due to inadequate financial literacy and spatial mobility, where internet access and technological advancement are yet in the infancy stage. Thus, to overcome such kind of supply issues, many firms and channels like payment banks, Peer to Peer (P2P) Lending, Online Wallets, Offline UPI (Unified Payment Interface) and Apps like BHIM emerged as the new dimension for digital transactions, especially after the demonetization drive. Further, this masterstroke movement caucused to think over the digital payment ecosystem with financial inclusion and digital economy.

The demonetization, being it is a means to eradicate black money circulations, it was not questioned ideally but liquidity crunch adversely affected on daily money requirements in many sectors especially in rural economy and unorganized sectors which are largely depending on cash based economy. The derived motto to move digitally over financial transactions and cashless economy is much far off being people are not well accustomed to digital and financial literacy and accessibility of smartphone and internet devices. Nevertheless, this operation will be led to digital financial inclusion subsequently many digital financial methods will be served to all people. Thus, money circulations and financial transactions will be more integrated and mobilized.

The inadequate digital and financial literacy is the major constraint to move on comprehensive digital financial inclusion. Apart from customers, many employers in the unorganized banking sector also are still illiterate and not tech-savvy, further they are not completely aware even about emerging digital banking procedures. The security issues over internet transactions and more often customers are facing operational risk. Therefore, to 
overcome these supply issues of digital financial services, there should be an intermediary channel which can be interoperable to sort out hindrances occurring in forwarding way of cashless or digitalized financial system.

The Business Correspondent (BC) services are resilient mode in some extent to solve such challenges of financial technology (Fintech) services among unbanked and undeserved rural people. It was launched in 2006 to work as agent of banks in the form of bricks and mortar branch especially in unbanked areas. After the launching of Pradhan Mantri Jan-Dhan Yojana (PMJDY) in 2014, BC Model got wide practices which are working as Customer Service Point (CSP) with digital devices like Point of Sale (POS), Mobile and internet banking. Now NBFCs and other Microfinance institutions also can be the BC by which millions of low income people will be customized to resolve difficulties occurred due to note bans and to literate the unbanked people with digital financial literacy. As per PMJDY inclusion statistics, 1,26,985 Bank Mitra are required in India as on 23.12.2016, but only 1,14,518 Active Bank Mitra are working well. It happens due to lower remuneration and not enabling them with advanced ICT and digital devices. However, In India FINO pay-tech is the mainstream BC with well mobilized digitalized services now it touches the lives of over 78 million customers through 28000 transaction points among 499 districts across 28 states in the country (Source: website info of FINO Payment Bank).

To tackle the challenges of moving towards financial technology, governments and other financial intermediaries have to play vital role with comprehensive steps. Mere launching of Apps like BHIM or online Wallet is not well enough to bridge the gap between cash and cashless economy, because India's massive economic sectors are unorganized or informal like daily wage workers, farmers and fishermen, they are typical and mainly depending on cash based routine, to them still digital economy or impact of demonetization is huge disruption on their livelihoods and well-being.

\section{CONCLUSIONS}

Irrespective of pros and cons of demonetization, this study mainly focused on discussing the deriving trends after this movement to transmit digitalized financial economy and inclusion. In this regards, banks, online wallets, NPCI, payment banks and emerging technology-based financial firms are doing diversified services and this study explored how can those services be utilized for financial inclusion and what is the impact of such services on financial inclusion.

Though this demonetization has brought adverse impact on the rural people and different business sectors at present, it should be taken up to connect the rural people with the banks digitally and conveniently. But above analyses based Number of accounts, No Frills accounts and Rupay Debit Card distribution reveal that there is no significant impact of demonetization on financial inclusion except in distribution of Rupay Debit card provided by Public sector banks. The paper remarkably draws a conclusion that, even BC services are practiced by Banks through bricks and mortar branches, banks and other financial firms have to focus on infrastructural utility services to all citizens with digital empowerment. More importantly, such institutions have to take crucial efforts to disseminate digital financial literacy, which is drastically lagging in many rural and unbaked areas, then only the mission for cashless or digital economy ultimately will be fulfilled. Eventually, it can be summarized more precisely in the light of analysis carried out in this study that the demonetization has impacted on accelerating digital financial inclusion across the country. 
Impact of Demonetization on Financial Inclusion in India: A Study with Evidence of Emerging Digital Financial Services

\section{REFERENCES}

[1] RBI. (2019). No. 43: Payment System Indicators. Reserve Bank of India Bulletin. May 2019. VOLUME LXXIII NUMBER $5 . \quad$ Accessed at https://www.rbi.org.in/scripts/BS_ViewBulletin.aspx

[2] Business Standard. (2019). Number Of Smartphone Users In India Likely To Double To 859 Million By 2022. May 10, 2019. Retrieved from: https://www.businessstandard.com/article/news-cm/number-of-smartphone-users-in-india-likely-to-double-to-859million-by-2022-119051000458_1.html

[3] Schueth. S, Alex Moler. (2017). The Effects of Demonetization on Financial Inclusion in India. Financial Inclusion Insights (FII) survey. Intermedia.

[4] RBI. (2017). Reserve Bank of India Bulletin. Volume LXXI Number-1. January-2017. Retrieved from http://www.bulletin.rbi.org.in

[5] Rajiv Singh. (2017). Banks vs mobile wallets: The slugfest. The Economic Times. Availableat:http://economictimes.indiatimes.com/articleshow $/ 56292074 . \mathrm{cms}$ ?utm_source $=$ con tentofinterest\&utm_medium=text\&utm_campaign=cppst

[6] Deep Raj. (2017). BHIM App Download. Available at: https://onepromocode.com/bhim-appwallet-offers/ accessed on 12.Jan, 2017

[7] Ajit Deshmukh. (2016). When Digital India ties in with financial inclusion. Digital India Program. Retrieved from: http://www.digitalindia.indiaincorporated.com/when-digital-indiaties-in-with-financial-inclusion/\#sthash.wvO0iN1c.dpuf

[8] Choudhury \& Sharma. (2016). How technology is disrupting financial inclusion in India. 17 JANUARY 2016. See link at: https://yourstory.com/2016/01/startup-india-fintech-panel/

[9] Susy cheston et.al. (2016). Insights From Banks In Emerging Markets. Institute of International Finance (IIF). Centre for Financial Inclusion. July. 2016

[10] Shivalik Chandan. (2016). RBI and Regulation of Digital Financial Services in India, 20122016. The centre for internet and society. Meta 11 July, 2016. See more at http://cisindia.org/raw/rbi-regulation-digital-financial-services-in-india-2012-2016

[11] PMJDY. (2016). Pradhan Mantri Jan Dhan Yojana. Available at: http://pmjdy.gov.in

[12] Sa-Dhan. (2016). The Bharat Microfinance Report 2016. NABARD. New Delhi: India

[13] Bank Bazar. (2016). https://www.bankbazaar.com/debit-card/rupay-debit-card.html

[14] Mishara Sharma. (2016). What Does India's Demonetization Experiment Mean for Financial Inclusion?. IFMR LEAD, Central for financial inclusion Blog. November, 2016.

[15] Villasenor, D et al. (2016). The 2016 Brookings Financial and Digital Inclusion Project (FDIP) Report. Advancing Equitable Financial Ecosystems. Washington: DC. August, 2016.

[16] KPMG. (2015). Role of digital banking in furthering financial inclusion. Financial Services. Retrieved from kpmg.com/in 
[17] Kate Lauer \& Timothy Lyman. (2015). Digital Financial Inclusion. Consultative Group to Assist the Poor. CGAP Annual Report 2016. Availabe at: http://www.cgap.org/publications/digital-financial-inclusion.

[18] Rishabh Khosla et.al. (2015). Digital Financial Inclusion in India: Taking Off in 2015. CGAP. 23 April 2015.

[19] CRISIL Inclusix. (2015). Financial Inclusion Index. Volume-III, June-2015

[20] LTP Team. (2014). Banking Correspondent: A Channel For Financial Inclusion in India \& Micro ATMs. Available at https://letstalkpayments.com/banking-correspondent-channelfinancial-inclusion-india/

[21] Neeru Chhabra. (2014). Financial Inclusion in India. Department of Economics Maharshi Dayanand University.

[22] Jaya Kumar Shetty, A. (2013). Effectiveness of Business Correspondent Model In Financial Inclusion and Empowering the Vulnerable. UGC Minor Research Project, South Western Regional Office, P.K Block, Gandinagar : Bangalore

[23] Rajaswaminathan, S. (2013). Financial Inclusion Initiatives of Commercial Banks in Nagapattinam District, Tamil Nadu. Manonmaniam Sundaranar University Tirunelveli - 627 012. Tamil Nadu, India

[24] Ujjawal, A. (2012). Business Correspondent Model an Analysis of the Financial Viability of Customer Service Providers and Client Satisfaction. IFMR Research Centre for Microfinance Centre for Micro Finance - IFMR Research, Chennai: India 